American Medical Journal 3 (2): 210-219, 2012

ISSN 1949-0070

(C) 2012 Science Publications

\title{
Aluminium Chloride Exposure Had No Effects on the Epididymis of Wistar Rats
}

\author{
${ }^{1}$ Adebayo Adekunle Buraimoh, ${ }^{2}$ Samuel Adeniyi Ojo, \\ ${ }^{2}$ Joseph Olajide Hambolu and ${ }^{1}$ Sunday Samuel Adebisi \\ ${ }^{1}$ Department of Human Anatomy, \\ Faculty of Medicine, Ahmadu Bello University, Zaria, Nigeria \\ ${ }^{2}$ Department of Veterinary Anatomy, \\ Faculty of Veterinary Medicine, Ahmadu Bello University, Zaria, Nigeria
}

\begin{abstract}
Aluminium is a ubiquitous element and one of the trace elements with moderate toxic effect on living organism. It is generally a recognized neurotoxin that is believed to be at the root cause of Alzheimer's disease and third most abundant element in the earth's crust after oxygen and silicon. Traditionally, aluminium has been considered as nontoxic to humans. However, in recent years, increased attention is being focussed on possible adverse effect of aluminium on human health. The epididymis is very important in the storage of sperm cell (spermatozoa). This study was conducted in order to evaluate the histological appearance of the epididymis following the oral administration of Aluminium Chloride. Ten wistar rats were used for this study. The wistar rats were divided into five groups as follows: Group I was the control that received distil water only, group II received $475 \mathrm{mg}$ $\mathrm{Kg}^{-1}$, group III received $950 \mathrm{mg} \mathrm{kg}{ }^{-1}$, group IV received $1,425 \mathrm{mg} \mathrm{kg}^{-1}$, group V received 1,900 mg $\mathrm{kg}^{-1}$ for duration of eight weeks; after which the wistar rats were humanely sacrificed, the epididymis removed and fixed in bouin's fluid. The epididymis was processed and stained in Haematoxylin and Eosin (H\&E). The histological observations revealed that there were no significant histological changes (effects) within the control and treated groups. Conclusion: Based on our observations, we therefore conclude that aluminium chloride had no significant effects on the histology of the epididymis and may not be detrimental to the cyto-architecture of the epididymis of wistar rats; therefore, storage of sperm in the epididymis could be safe.
\end{abstract}

Key words: Epididymis, wistar rats, aluminium chloride, exposure

\section{INTRODUCTION}

Epididymis is part of the male reproductive system present in all male amniotes. It is a narrow structure within the scrotum, with tightly-coiled tube connecting the efferent ducts from the rear of each testicle to its vas deferens (that is attached to the back side of the testis). It is a coiled segment of the spermatic ducts that stores spermatozoa while they mature and then transports the spermatozoa between the testis and the tube connecting the testes with the urethra (vas deferens).

The epididymis can be divided into three main regions:

- The head (Caput). The head of the epididymis receives spermatozoa via the efferent ducts of the mediastinum of the testis. It is characterized histological by a thin myoepithelium. The concentration of the sperm here is dilute

- The body (Corpus)

- The tail (Cauda)

This has a thicker myoepithelium than the head region, as it is involved in absorbing fluid to make the sperm more concentrated. In reptiles, there is an additional canal between the testis and the head of the epididymis, which is painful when hit and which receives the various efferent ducts. This is, however, absent in all birds and mammals (Romer and Parsons 1977). The epididymis is covered by a two layered pseudo-stratified epithelium. The epithelium is separated by a basement membrane from the connective tissue wall which has smooth muscle cells. The major cell types in the epithelium are:

Corresponding Author: Adebayo Adekunle Buraimoh, Department of Human Anatomy, Faculty of Medicine, Ahmadu Bello University, Zaria, Nigeria Tel: +234-8028193042 
- Principal cells: columnar cells, with the basal cells, form the majority of the epithelium. These cells extend from the lumen to the basal lamina. They also have non-motile stereo cilia, which are long and branching in the head region and shorter in the tail region. They also secrete carnitine, sialic acid glycoproteins and glycerylphosphorylcholine into the lumen

- Basal cells: shorter, pyramid-shaped cells which contact the basal lamina but taper off before their apical surfaces reach the lumen. These are thoght to be undifferentiated precursors of principal cells

- Apical cells: predominantly founud in the head region

- Clear cells: predominant in the tail region

- Intraepithelial lymphocytes: distributed throughout the tissue (Kierszenbaum, 2002)

Spermatozoa formed in the testis enter the caput epididymis, progress to the corpus and finally reach the cauda region, where they are stored. Sperm entering the caput epididymis are incomplete-they lack the ability to swim forward (motility) and to fertilize an egg. During their transit in the epididymis, sperm undergo maturation processes necessary for them to acquire these functions. Final maturation is completed in the female reproductive tract (capacitation). During ejaculation, sperm flow from the lower portion of the epididymis (which functions as a storage reservoir). They have not been activated by products from the prostate gland and they are unable to swim, but are transported via the peristaltic action of muscle layers within the vas deferens and are mixed with the diluting fluids of the seminal vesicles and other accessory glands prior to ejaculation (forming semen).

Sperm cells produced in the testes are transported to the epididymis, where they mature and are stored. Each epididymis has three regions, called, respectively, the head, body and tail. The head is the uppermost and largest part of the epididymis; it lies on the top surface of the testis. The body is attached to the anal side of the testis and extends the length of the gland. The smallest region is the tail, which begins at the point of separation of the epididymis from the testis. Sperm cells mature primarily in the head and body of the epididymis and are stored in the tail. The epididymis receives sperm from the tubules in the mediastinum testis, the region in the testis in which all its sperm-producing tubules converge and empty. Leading from the mediastinum to the head of the epididymis are 15-20 small, tightly coiled ducts called the ductuli efferentes. The cells lining the ductuli have pigment granules, secretory granules and cilia (hair like structures). In the head region of the epididymis, all the ductuli efferentes connect to one large vessel, the ductus epididymidis. This duct is also extremely coiled, being about 4 to $5 \mathrm{~m}$ (13 to 16 feet) long when stretched out. The ductus epididymidis extends through both the body and the tail region of the epididymis. In the tail region it becomes thicker, less coiled and larger in diameter. As it emerges from the end of the epididymis, it straightens out to form the ductus deferens (Jones, 1999; Ross and Pawlina, 2011).

Aluminium is one of the trace elements with moderate toxic effect on living organism. It is the third most abundant element in the earth's crust after oxygen and silicon. It occurs in nature in combination with other elements such as oxygen, silicon and fluoride. Traditionally, aluminium has been considered as nontoxic to humans. However, in recent years, increased attention is being focussed on possible adverse effects of aluminium on human health. Human exposure to aluminium is from its natural occurrence in the environment i.e. through food, water and air, as well as, from aluminium deliberately introduced into the environment by man. The main food sources of aluminium are: hard cheese, grain products (flour), herbs and tea leaves. Chronic exposition to this trace element can cause alterations in skeletal, nervous, hematopoietic and respiratory systems (Afifi, 2002; Campbell, 2002; Chen et al., 2002; Plieth et al., 1999). Aluminium compounds are used in pharmaceuticals (antacids, analgesics, antiperspirants) in water treatment processes (as coagulant) and as metal in consumer products.

Aluminium is present in virtually all plants. Foods naturally high in aluminium include potatoes, spinach and tea. Processed dairy products, flour and infant formula may be high in aluminium, if they contain aluminium compounds as food additives (WHO, 1998). Aluminium in natural waters depends on the source. It was observed that ground waters had low aluminium levels as compared to surface waters (Millar et al., 1984). At neutral $\mathrm{pH}$, it may range from 0.01 to 0.05 $\mathrm{mg} \mathrm{L}^{-1}$, except in turbid waters (WHO, 1998). Higher concentrations can be present in acidic water or in the presence of organic compounds even at neutral $\mathrm{pH}$. There are several reports on the increase of total aluminium concentration in treated water as compared to raw water (Millar et al., 1984; Cech and Montera, 2000; Lettermann and Driscoll, 1988).

Aluminium is a possible contributing factor in Alzheimer's disease (Campbell, 2002). Evidence for the contribution of Aluminium to Alzheimer's Disease (AD) remains contradictory (Flaten, 2001; Gupta et al., 2005). However, epidemiological studies have 
indicated a link between Aluminium in drinking water and $\mathrm{AD}$ and a variety of human and animal studies have implicated learning and memory deficits after Aluminium exposure (Buraimoh et al., 2011a; Exley, 2005; Yokel, 2000). The aim of this study was to evaluate the histological appearance of the epididymis following the oral administration of Aluminium Chloride.

\section{MATERIALS AND METHODS}

This experiment was conducted in the Department of Human Anatomy, Faculty of Medicine, Ahmadu Bello University, Zaria, Kaduna State, Nigeria. The rules and regulations governing animal care were observed.

Experimental animals: Ten male wistar rats were used for this experiment. The wistar rats were housed in steel cages maintained at good environmental conditions with sufficient food, water and under good ventilation. The wistar rats were kept for two weeks before commencement of Aluminium chloride administration. This was to enable the wistar rats acclimatized to the environment.

Experimental design: The wistar rats were divided into five groups: group I (control) was given distil water while the four Aluminium exposed groups were given various concentrations of aluminium chloride as follows:

$$
\begin{array}{cc}
\text { Group II received } & 475 \mathrm{mg} \mathrm{Kg}^{-1} \\
\text { Group III received } & 950 \mathrm{mg} \mathrm{kg}^{-1} \\
\text { Group IV received } & 1,425 \mathrm{mg} \mathrm{kg}^{-1} \\
\text { Group V received } & 1,900 \mathrm{mg} \mathrm{kg}^{-1}
\end{array}
$$

The route of administration was through oral intubation, LD50 was $3,800 \mathrm{mg} \mathrm{kg}^{-1}$ and the duration of administration was Eight weeks. After eight weeks of administration, the wistar rats were humanely sacrificed and the epididymis was removed and immediately fixed in bouin's fluid. The epididymis was then transferred into an automatic tissue processor where they went through a process of dehydration in ascending grades of alcohol 70, 80, 95\% and absolute alcohol for 2 changes each. The tissues were then cleared in Xylene and embedded in paraffin wax. Serial sections of 5 micron thick were obtained using a rotary microtome. The tissue sections were deparaffinised, hydrated and stained using the routine haematoxylin and eosin staining method (H\&E) (Gurr, 1962). The stained sections were examined under the light microscope fitted to a laptop and digital camera for photomicrographs at magnifications of X40 and X100 for each group.

\section{RESULTS AND DISCUSSION}

Epididymis is a narrow structure within the scrotum, with tightly-coiled tube connecting the efferent ducts from the rear of each testicle to its vas deferens (that is attached to the back side of the testis). It is a coiled segment of the spermatic ducts that stores spermatozoa while they mature and then transports the spermatozoa between the testis and the tube connecting the testes with the urethra (vas deferens) (Kierszenbaum, 2002; Jones, 1999).

Aluminium was said to have contributed to a variety of cognitive impairments in mice, rabbits and rat pups (Muller et al., 1990; Yokel, 1985, BilkeiGorzo, 1993; Mari et al., 2001). Behavioural impairment has also been reported in wistar rats exposed to soluble aluminium salts (chloride) in the drinking water (Buraimoh et al., 2011b). Both rats (Connor et al., 1988) and mice (Yen-Koo, 1992) have demonstrated such impairments at doses exceeding 200 $\mathrm{mg}$ of aluminium per $\mathrm{kg}$ of body weight per day. Aluminium chloride was said to have negative effects on anxiety-related behaviour of wistar rats as indicated by increased rate of anxiety in Aluminium treated rats (Buraimoh et al., 2011c).

Other reports on occupational Aluminium exposure and neurological impairments demonstrate mixed findings (Sim et al., 1997). Despite strong experimental and clinical evidence for Aluminum neurotoxicity, the mechanism of Aluminium effects on the nervous system is still not completely clear. Buraimoh et al. (2012a) reported that Aluminium chloride exposure has neurodegenerative effects on the histology of cerebral cortex of adult wistar rats especially at higher dose as evident in aluminium treated groups which showed extensive neuronal vacuolation and necrosis (neuro-degeneration) of the cerebral cortex of wistar rats. It was also estimated that there was graded increased in brain Aluminium uptake of wistar rats across the groups as the group that received the highest dose had highest brain aluminium uptake which was dose dependent (Buraimoh et al., 2012b).

In the present study, we observed normal histological appearances (features) of the epididymis of the control (Fig. 1 and 2) even when compared with the aluminium treated groups (Fig. 3-10). There was accumulation of spermatozoa seen in several luminal spaces with well arranged ductulus efferens around the lumens for both the control, i.e., group I (Fig. 1 and 2) and aluminium treated groups, i.e., groups II-V (Fig. 3-10). 
Am. Med. J. 3 (2): 210-219, 2012

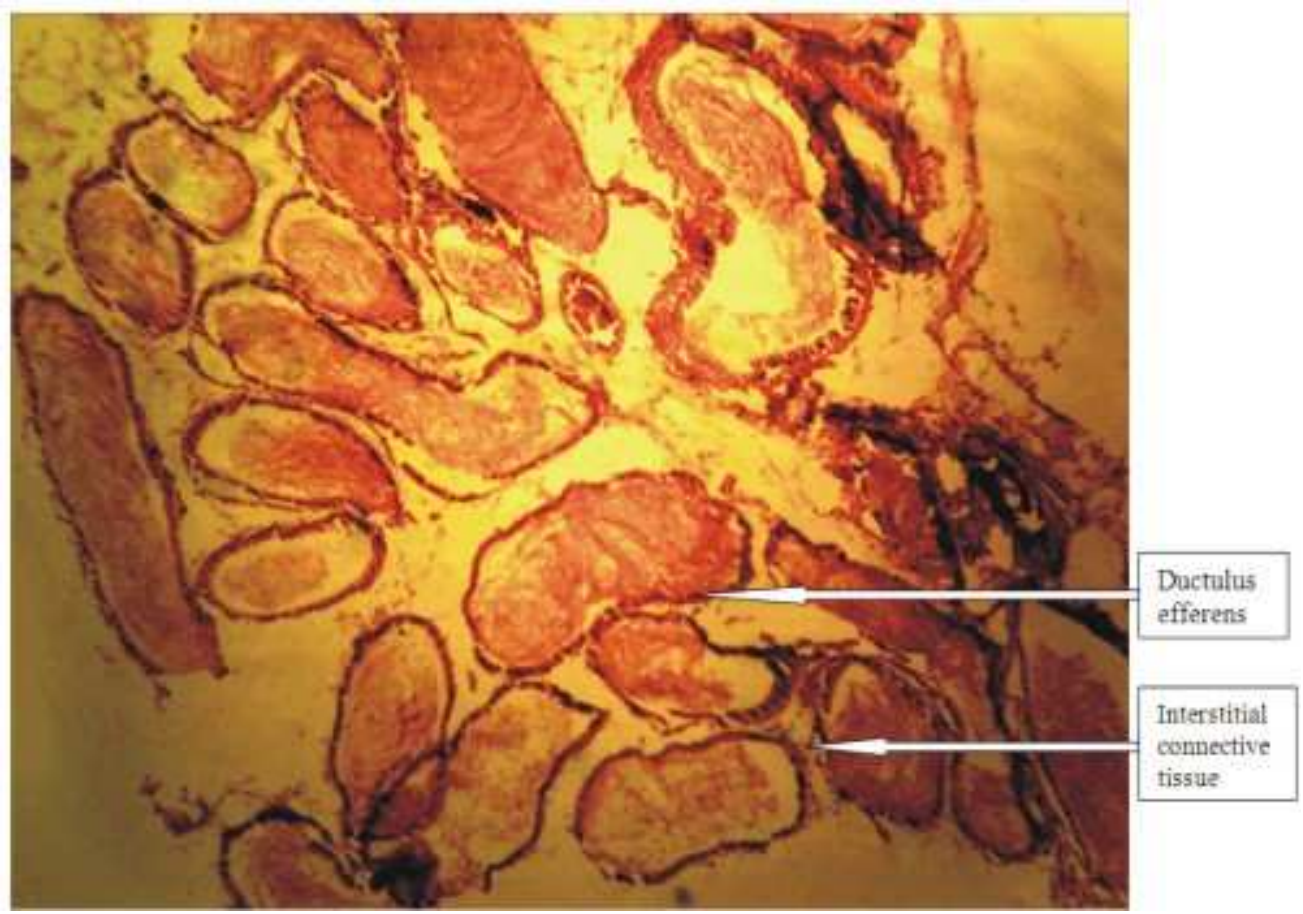

Fig. 1: Photomicrograph of the Epididymis of Wistar rats of group I (control) stained with H\&E. X40

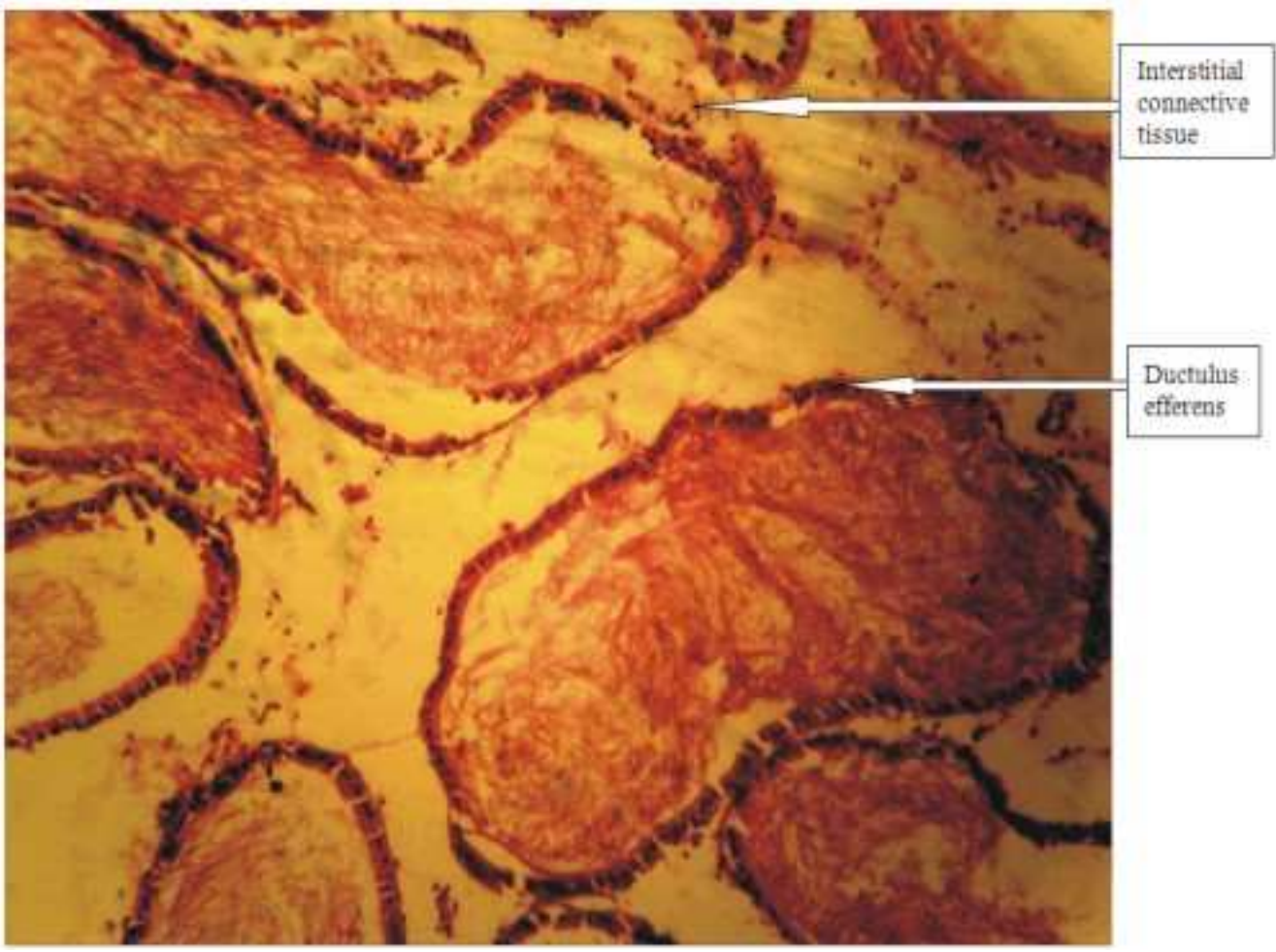

Fig. 2: Photomicrograph of the Epididymis of Wistar rats of group I (control) stained with H\&E. X100 
Am. Med. J. 3 (2): 210-219, 2012

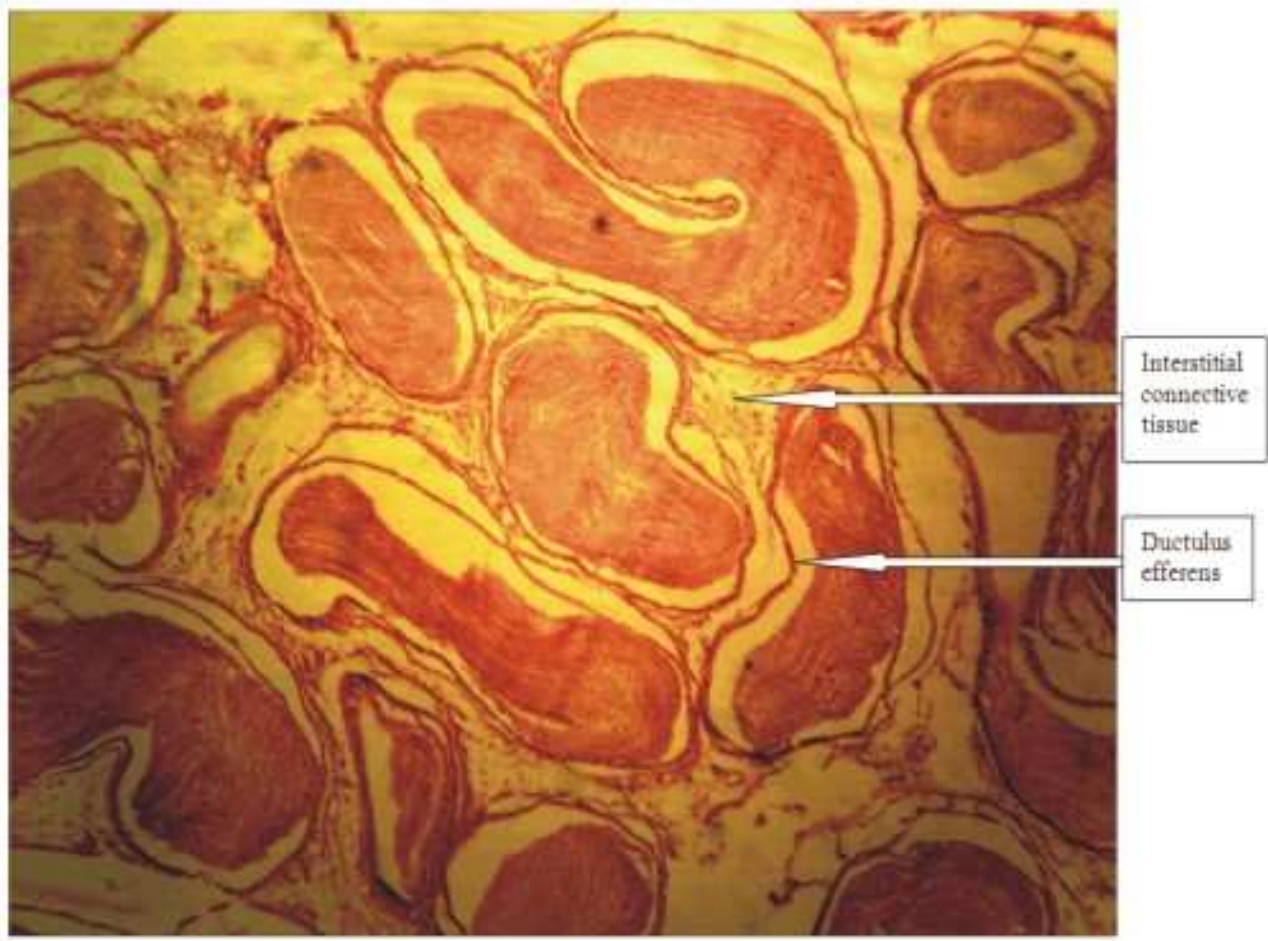

Fig. 3: Photomicrograph of the Epididymis of Wistar rats of group II stained with H\&E. X40

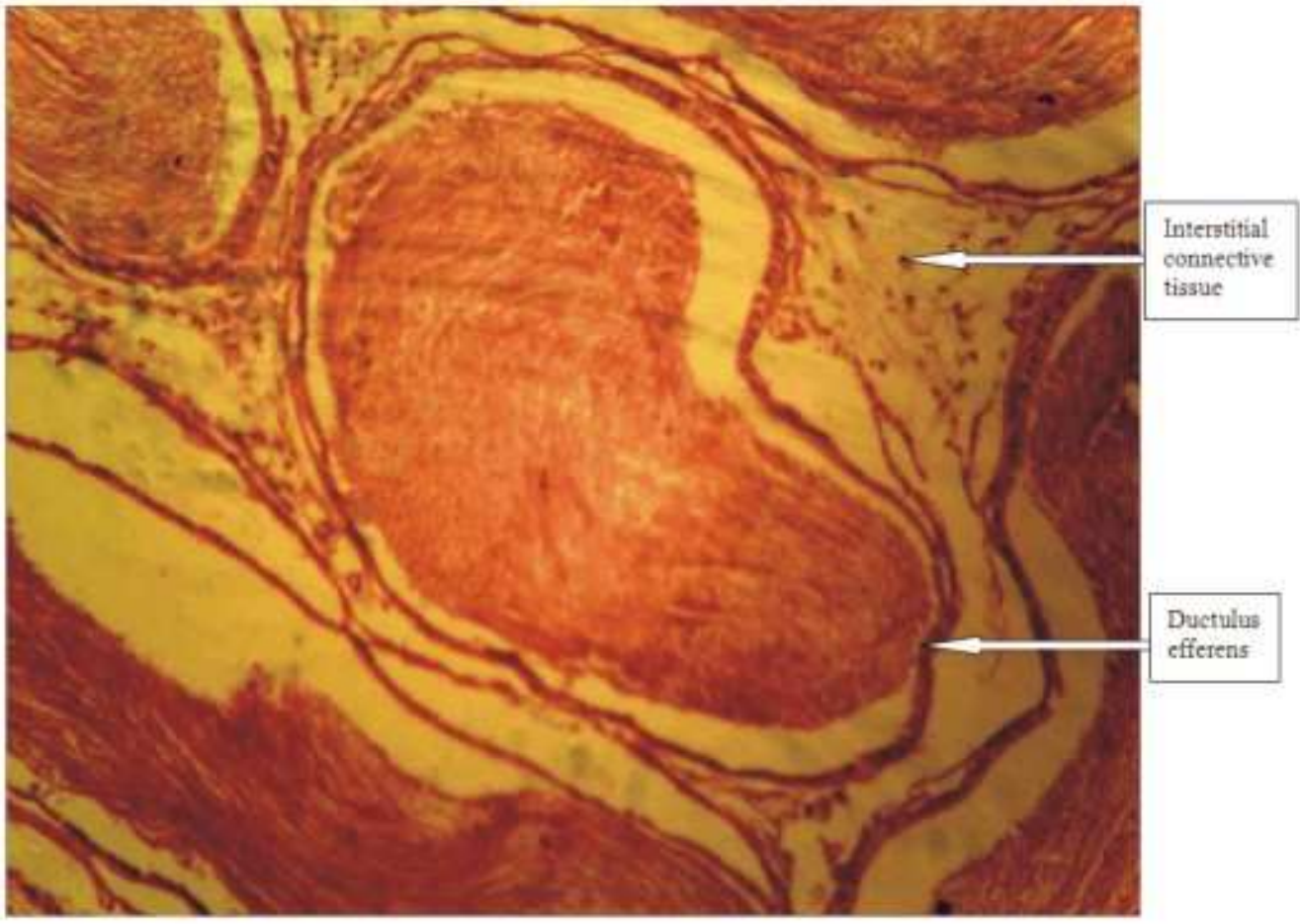

Fig. 4: Photomicrograph of the Epididymis of Wistar rats of group II stained with H\&E. X100 
Am. Med.J. 3 (2): 210-219, 2012

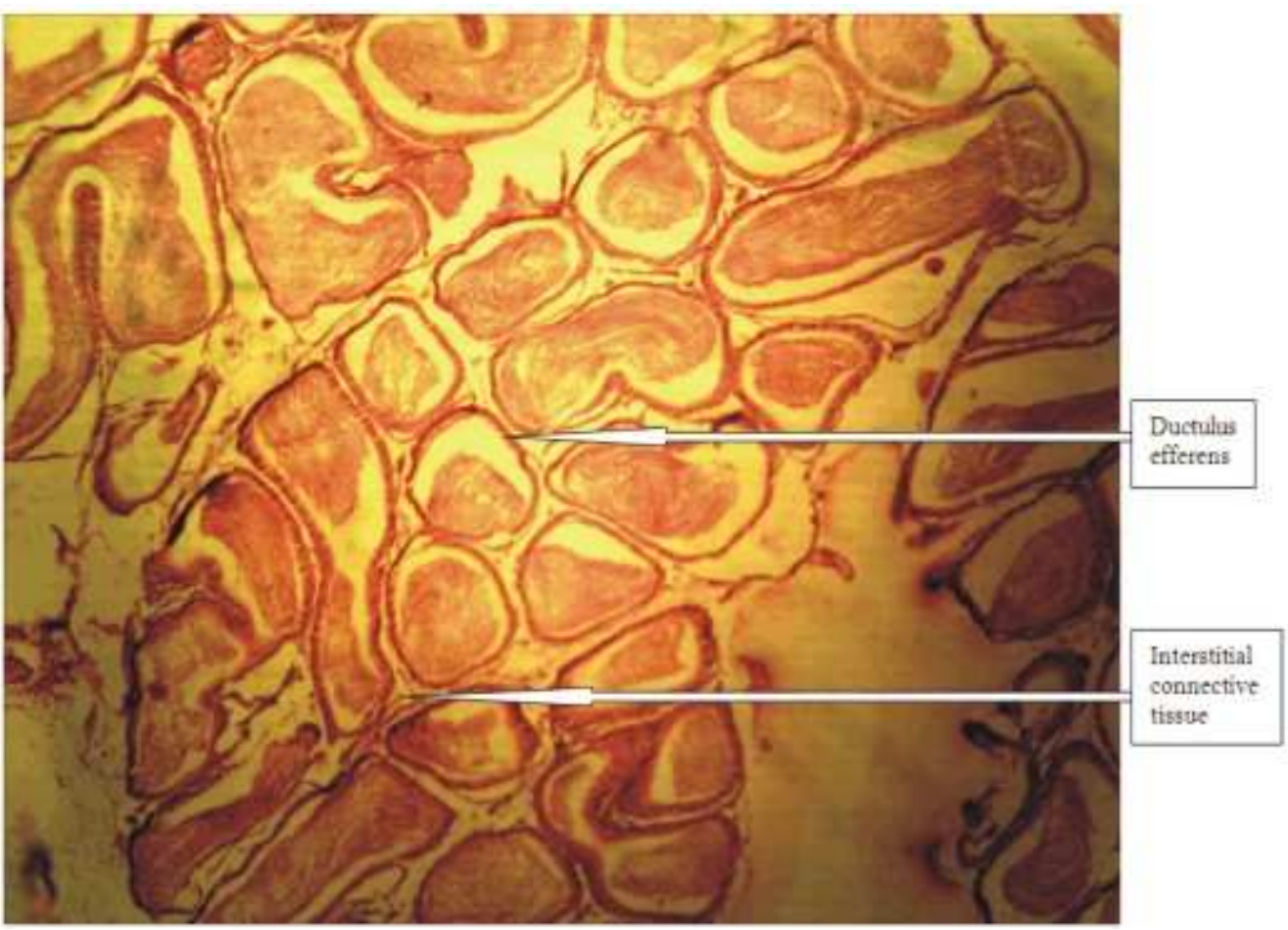

Fig. 5: Photomicrograph of the Epididymis of Wistar rats of group III stained with H\&E. X40

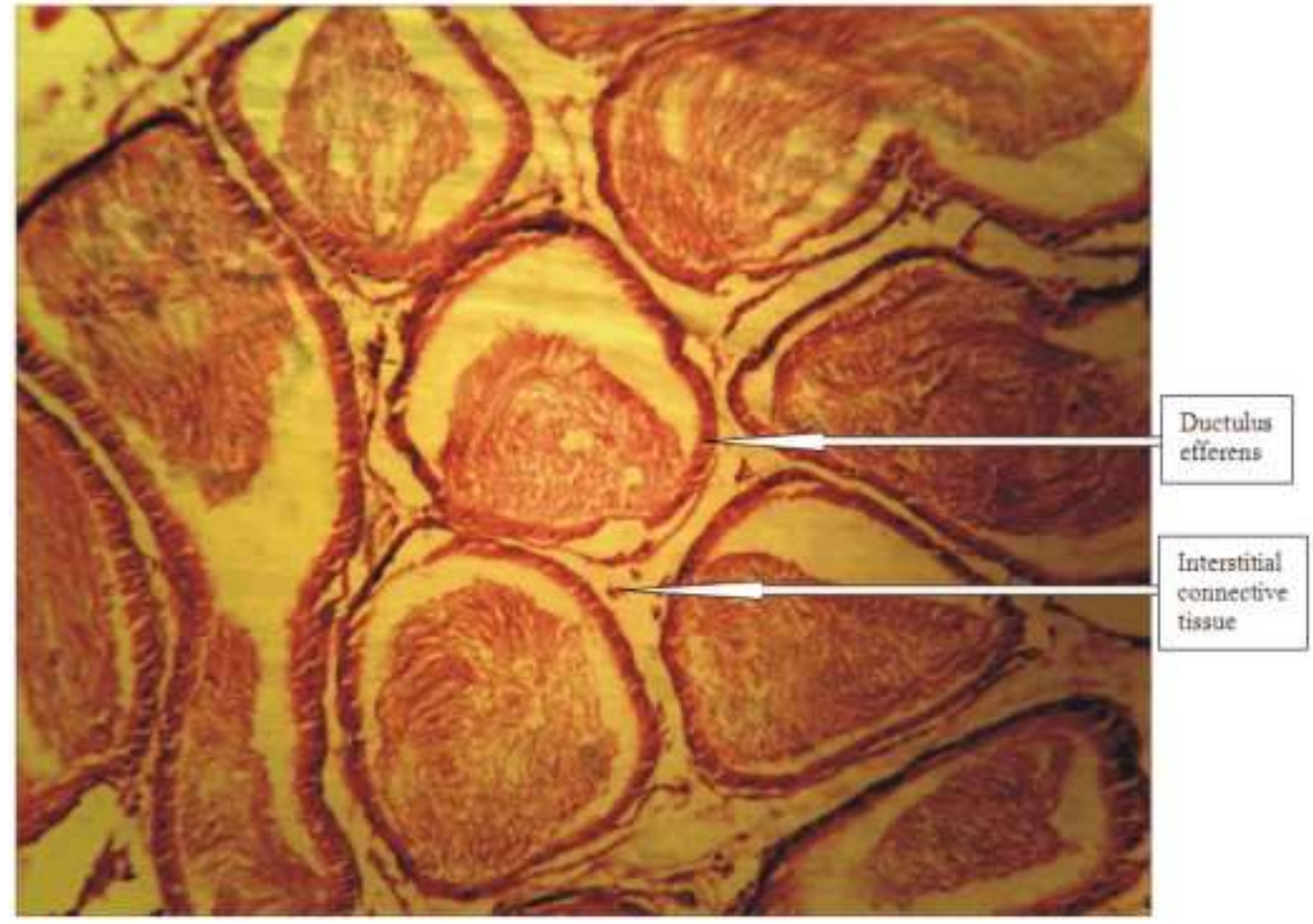

Fig. 6: Photomicrograph of the Epididymis of Wistar rats of group III stained with H\&E. X100 
Am. Med. J. 3 (2): 210-219, 2012

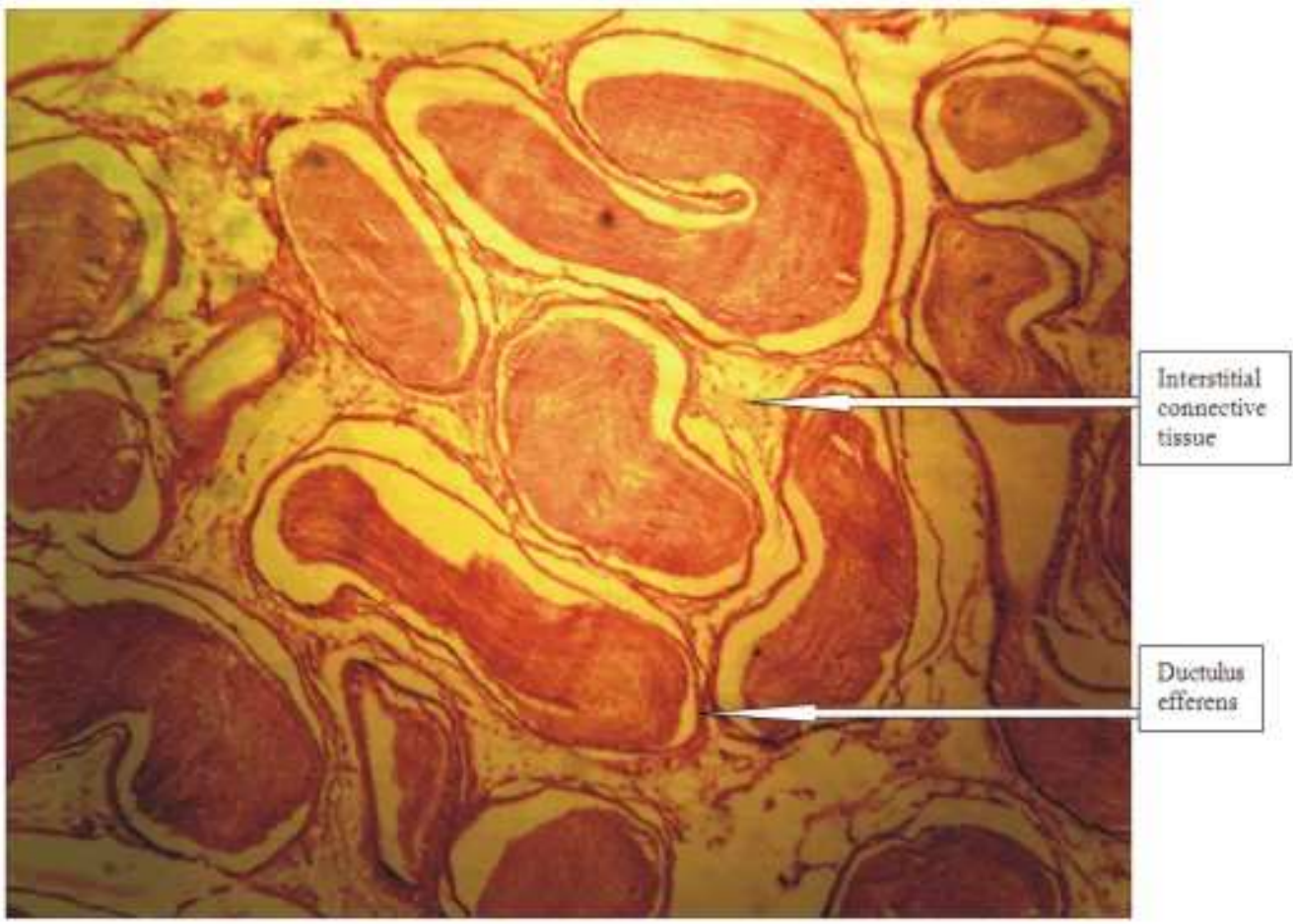

Fig. 7: Photomicrograph of the Epididymis of Wistar rats of group IV stained with H\&E. X40

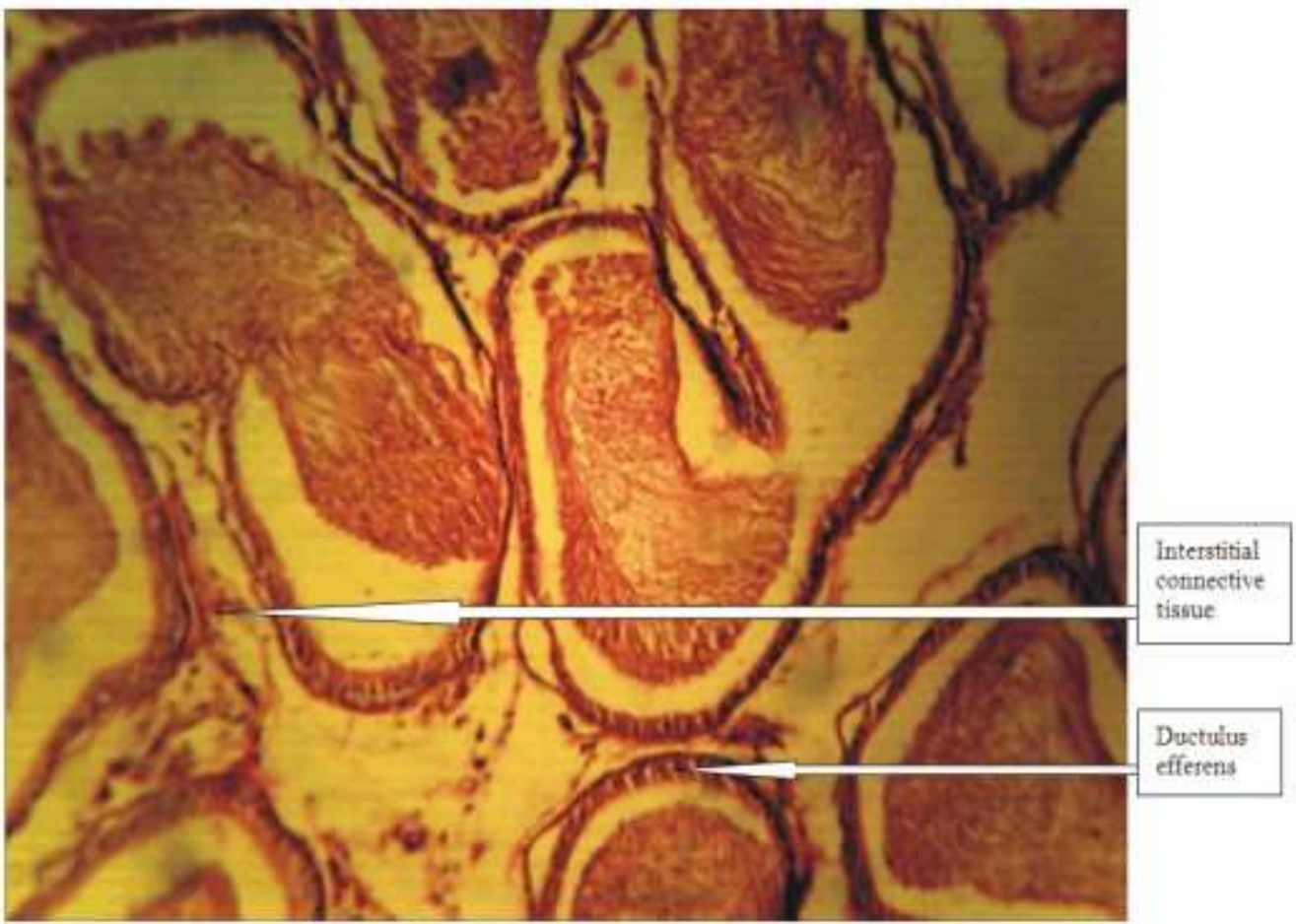

Fig. 8: Photomicrograph of the Epididymis of Wistar rats of group IV stained with H\&E. X100 


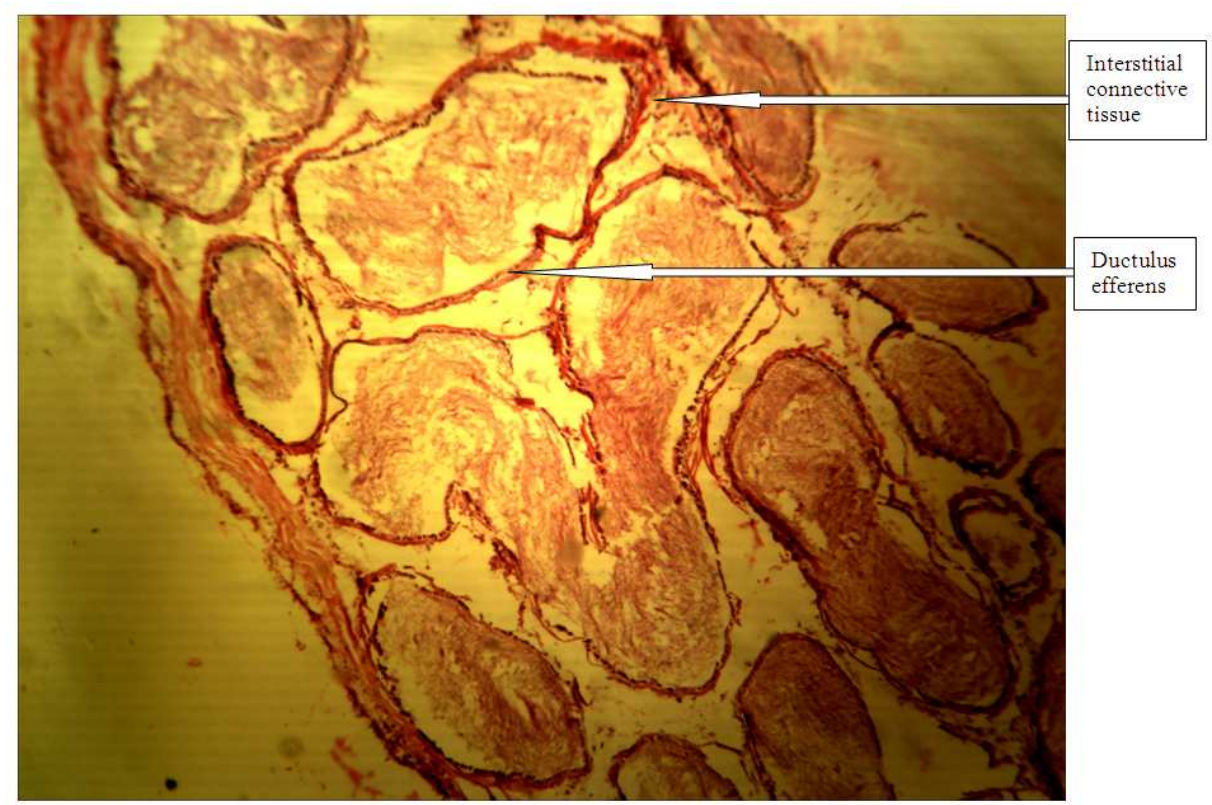

Fig. 9: Photomicrograph of the Epididymis of Wistar rats of group V stained with H\&E. X40

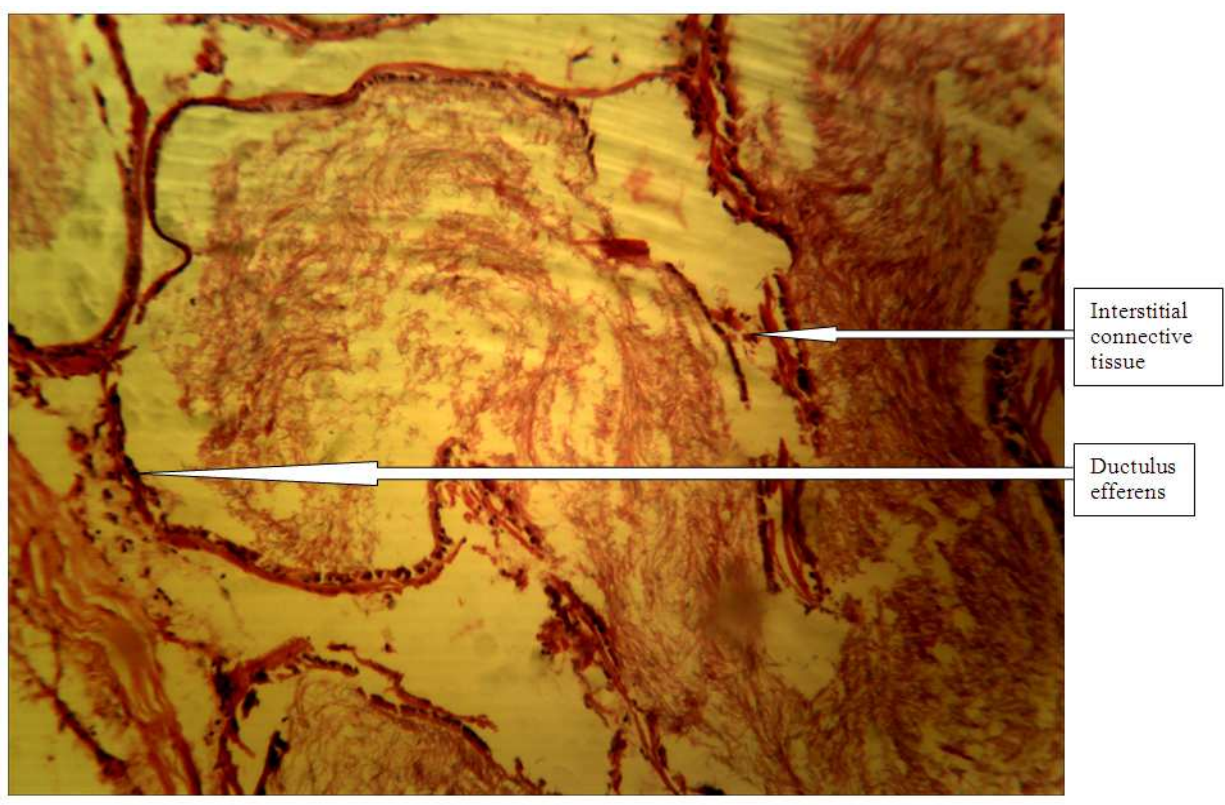

Fig. 10: Photomicrograph of the Epididymis of Wistar rats of group V stained with H\&E. X100

Our findings were in contrast to that of Buraimoh et al. (2012d) which stated that aluminium chloride exposure could be detrimental to the integrity of the testes of wistar rats. However, the findings of Buraimoh et al. (2012c) indicated that although, aluminium chloride decreased the level of sperm count, but it did not result into infertility; this they reported could be as a result of the fact that the wistar rats that received the highest dose of aluminium chloride $\left(1,900 \mathrm{mg} \mathrm{kg}^{-1}\right)$ had an average sperm count of 19.75 million $\left(10^{6}\right)$ which was close to 20 million sperm count required for fertility while the other treated groups had sperm count above 20 million per milliliters. 
In our present study, we observed that the ductulus efferens, interstitial connective tissue, as well as, the spermatozoa in the lumen were intact (Fig. 110).

Our present study, therefore, affirmed that the capability of the epididymis to store the sperm cell despite the oral exposure to aluminium chloride could be part of the reasons why the aluminium treated wistar rats in Buraimoh et al. (2012c) study were said to be fertile.

\section{CONCLUSION}

Based on our observations, we therefore conclude that Aluminium Chloride Exposure had no effects on the histology of the epididymis and hence storage of sperm cells (spermatozoa) by the epididymis could be safe.

\section{ACKNOWLEDGEMENT}

The researchers wish to acknowledge the Authority of Ahmadu Bello University, Zaria, Nigeria, for supporting this research work.

\section{REFERENCES}

Afifi, A., 2002. Renal osteodystrophy in developing countries. Artif. Organs., 26: 767-769. PMID: 12197931

Bilkei-Gorzo, A., 1993. Neurotoxic effect of enteral aluminium. Food Chem. Toxicol., 31: 357-361. PMID: 8505021

Buraimoh, A.A., S.A. Ojo, J.O. Hambolu and S.S. Adebisi, 2011a. Effects of oral administration of aluminium chloride on the histology of the hippocampus of wistar rats. Curr. Res. J. Biol. Sci., 3: 509-515.

Buraimoh, A.A., S.A. Ojo, J.O. Hambolu and S.S. Adebisi, 2011b. Behavioural enpoints of adult wistar rats, following aluminium chloride exposure. Br. J. Pharmacol. Toxicol., 2: 273-276.

Buraimoh, A.A., S.A. Ojo, J.O. Hambolu and S.S. Adebisi, 2011c. Effects of aluminium chloride on anxiety-related behaviour. Am. J. Neurosci., 2: 6569. DOI: 10.3844/amjnsp.2011.65.69

Buraimoh, A.A., S.A. Ojo, J.O. Hambolu and S.S. Adebisi, 2012a. Effects of aluminium chloride exposure on the histology of the cerebral cortex of adult wistar rats. J. Biol. Life Sci. DOI: 10.5296/jbls.v3i1.1421
Buraimoh, A.A., S.A. Ojo, J.O. Hambolu and S.S. Adebisi, 2012b. Brain aluminium uptake of adult wistar rats following the oral administration of aluminium chloride. Eur. J. Sci. Res., 72: 576-582.

Buraimoh, A.A., S.A. Ojo, J.O. Hambolu and S.S. Adebisi, 2012c. Effects of aluminium chloride exposure on the sperm count of adult malewistar rats. Asian J. Exp. Biol. Sci., 3: 439-442.

Buraimoh, A.A., S.A. Ojo, J.O. Hambolu and S.S. Adebisi, 2012d. Histological study of the effects of aluminium chloride exposure on the testis of wistar rats. Am. Int. J. Contemporary Res., 2: 114-122.

Campbell, A., 2002. The potential role of aluminium in Alzheimer's disease. Nephrol. Dial. Transplant, 17: 17-20. PMID: 11904353

Cech, I. and J. Montera, 2000. Spatial variations in total aluminum concentrations in drinking water supplies studied by Geographic Information System (GIS) methods. Water Res., 34: 2703-2712. DOI: 10.1016/S0043-1354(00)00026-9

Chen, J., M. Wang, D. Run and J. She, 2002. Early chronic aluminium exposure impairs long-term potentiation and depression to the rat dentate gyrus in vivo. Neuroscience, 112: 879-887. PMID: 12088747

Connor, D.J., R.S. Jope and L.E. Harrell, 1988. Chronic, oral aluminum administration to rats: Cognition and cholinergic parameters. Pharmacol. Biochem., Beha., 31: 467-474. PMID: 2854266

Exley, C., 2005. The aluminium-amyloid cascade hypothesis and Alzheimer's disease. Subcell Biochem., 38: 225-234. PMID: 15709481

Flaten, T., 2001. Aluminium as a risk factor in Alzheimer's disease, with emphasis on drinking water. Brain Res. Bull., 55: 187-196. PMID: 11470314

Gupta, V.B., G. Anitha, M.L. Hegda, L. Zecca and R.M. Garruto et al.,, 2005. Aluminium in Alzheimer's disease: Are we still at a crossroad? Cell Mol. Life Sci., 62: 143-158. PMID: 15666086

Gurr, E., 1962. Staining Animal Tissues: Practical and Theoretical. 1st Edn., L. Hill, London, pp: 631.

Jones, R., 1999. To store or mature spermatozoa? The primary role of the epididymis. Int. J. Androl., 22: 57-67. DOI: 10.1046/j.1365-2605.1999.00151.x

Kierszenbaum, A.L., 2002. Histology and Cell Biology: An Introduction to Pathology. 4th Edn., Mosby, St. Louis, ISBN-10: 0323016391, pp: 619.

Lettermann, R.D. and C.T. Driscoll, 1988. Survey of residual aluminium in filtered water. J. Am. Water Works Assoc., 80: 154-154. 
Mari, S., Golub and L. Stacey, 2001. Long-term consequences of developmental exposure to aluminum in a suboptimal diet for growth and behavior of Swiss Webster mice. Neurotoxicol. Teratol., 23: 365-372. PMID: 11485839

Millar, G.G., F.C. Kopfler, K.C. Kelty, J.A. Stober and N.S. ULmar, 1984. The occurrence of aluminium in drinking water. J. Am. Water Assoc., 76: 84-91.

Muller, G., V. Bernuzzi, D. Desor, M.F. Hutin and D. Burnel et al., 1990. Developmental alterations in offspring of female rats orally intoxicated by aluminum lactate at different gestation periods. Teratol., 42: 253-261. PMID: 2274891

Plieth, C., B. Sattelmacher, U.P. Hansen and M.R. Knight, 1999. Low-pH-mediated elevations in cytosolic calcium are inhibited by aluminium: A potential mechanism for aluminium toxicity. Plant J., 18: 643650. PMID: 10417715

Romer, A.S. and T.S. Parsons, 1977. The Vertebrate Body. 6th Edn., Holt Rinehart and Winston, ISBN10: 0030584469, pp: 656.
Ross, M.H., G.I. Kaye and W. Pawlina, 2011. Histology: A Text and Atlas. 4th Edn., Lippincott Williams and Wilkins, ISBN-10: 0683302426, pp. 875 .

Sim, M., R. Dick, J. Russo, B. Bernard and C. Mueller et al., 1997. Are aluminium potroom workers at increased risk of neurological disorders? Occup. Environ. Med., 54: 229-235. PMID: 9166127

WHO, 1998. Guidelines for Drinking-Water Quality. 2nd Edn., World Health Organization, Geneva, ISBN: 92-4-154460.

Yen-Koo, H.C., 1992. The effect of aluminum on Conditioned Avoidance Response (CAR) in mice. Toxicol. Ind. Health, 8: 1-7. PMID: 1542881

Yokel, R.A., 1985. Toxicity of gestational aluminum exposure to the maternal rabbit and offspring. Toxicol. Applied Pharmacol., 79: 121-133. PMID: 4049399

Yokel, R.A., 2000. The toxicology of aluminum in the brain: A review. Neurotoxicology, 21: 813-828. PMID: 11130287 